\title{
Demobilization and social reintegration of Brazilian and American troops of World War II:
}

\author{
A COMPARATIVE STUDY*
}

\author{
Desmobilização e reintegração social das tropas brasileiras e \\ americanas da Segunda Guerra Mundial: um estudo comparativo
}

Francisco Cesar Alves Ferraz ${ }^{1}$

\begin{abstract}
The aim of this work is to discuss the results of a comparative study of demobilization and social reintegration of Brazilian and American veterans of World War II. . In spite of the obvious difference in scale of the two military experiences, I argue that the study of the two experiences can offer new insights into lights on various common issues to both countries: the relationship between the societies and their armed forces, between the governments and their citizens, social and racial inequalities and, finally, the experiences of building welfare state structures during the war and postwar periods. Based on international studies of demobilization and social integration war veterans, the variables that were decisive for the success or failure of adaptation were: a) past experiences in the reintegration of war veterans; $b$ ) the nature and consequences of recruitment of future veterans; c) planning by the State and the Armed Forces of procedures for post-bellum demobilization and reintegration; d) the implementation of demobilization and the effects within the military institution and in civil society.
\end{abstract}

Keyword: World War II. United States. Brazil. Demobilization. War Veterans.

\footnotetext{
* This article is based on a Paper presented at Institute on World War II and the Human Experience (IWWHE), Florida State University, Tallahassee, FL, on February, 17, 2012, as part of Seminar "World War II and the Human Experience: Recognition and Remembrance". I would like to acknowledge the comments and suggestions from researchers of the IWWHE, particularly its Director, Professor G. Kurt Piehler. I owe special thanks to Prof. Frank D. McCann (University of New Hampshire), for his patience and attention in reading this text and for his invaluable advice. Of course that I bear full responsibility for remaining errors and misconceptions.

1 Department of History - Universidade Estadual de Londrina, Brazil. Research Scholar at University of Tennessee, Knoxville, TN (2011-2012). Research funded by CAPES Foundation, Ministry of Education of Brazil, Brasilia, DF, Brazil.
} 


\section{RESUMO}

O objetivo deste artigo é discutir os resultados de um estudo comparativo dos veteranos brasileiros e americanos da Segunda Guerra Mundial, com respeito à sua desmobilização e reintegração social. Apesar das óbvias diferenças entre as experiências da participação na guerra entre Estados Unidos e Brasil, defendo que o estudo dessas duas maneiras de lidar com os problemas de desmobilização e reinserção dos combatentes pode oferecer novas luzes sobre vários problemas comuns a ambos os países: a relação entre as sociedades e as forças armadas, as relações entre o governo federal e os seus cidadãos, a desigualdade social e racial e, por último mas não menos importante, as experiências de construção de estruturas de Estado de Bem Estar na guerra e pós-guerra. Baseada em estudos internacionais sobre processos lidando com a desmobilização e integração social dos ex-combatentes da guerra, essa pesquisa atual selecionou as variáveis que foram decisivas para o sucesso ou o fracasso de tal uma adaptação em tempo de paz: a) experiências anteriores de reinserção dos veteranos de guerra; b) a natureza e as consequências do recrutamento para os futuros ex-combatentes; c) o planejamento do Estado e das forças armadas dos processos de desmobilização e reintegração no pós-guerra; d) a implementação de desmobilização e os impactos no seio da instituição militar e da sociedade civil causados pela reintegração de ex-combatentes à vida social e profissional.

Palavras-Chave: Segunda Guerra Mundial. Estados Unidos. Brasil. Desmobilização. Veteranos de Guerra.

The demobilization of combat troops after a war featuring large contingents of conscripted people and their return to their homes and to their social and professional activities is one of the most complex problems resulting from $20^{\text {th }}$ century wars. When millions of citizens from dozens of countries were conscripted during World War II, the problem reached the throes of paroxysm. Current essay will summarize the results of a comparative study of demobilization and social reintegration of Brazilian and American veterans of World War.

Although the USA and Brazil were allies, obviously their contribution towards victory had different approaches and proportions. The USA's sixteen million under arms and powerful war industries were decisive in crushing the Axis. At that time Brazil was mostly economically undeveloped although it contributed to the war effort with strategic prime materials, airfields, naval bases and supplies for the allies. Moreover, an army division with 25,000 combatants and a squadron of fighters served in Italy during 1944-1945.

Since the profiles of the two countries are so different, at first comparative research may seem pointless. However, I argue that the study of two ways of dealing with the problems of demobilization and reintegration of combatants, can offer new insights into various common issues such as the relationship between society and the armed forces, relations between the federal government and its citizens, social and racial inequality and, last but not least, the welfare state experiences in the postwar period. Therefore, this research is based on the following: a) citizens-soldiers of both countries literally fought side by side during the Italian campaign and shared similar experiences on the front; 2 ) because 
of the experience of the Brazilian Expeditionary Force, the Brazilian army modeled its organization on that of the US army; c) the US demobilization of the World War II became an example for all capitalist countries for the re-insertion of their citizen-soldiers into the post-bellum civil world; $d$ ) the different forms of demobilization of citizen-soldiers and their integration into civil society revealed the concepts and practices of citizenship in each country.

Within the context of research with such evident economic and military differences, factors which do not depend on the size of armies or on the material capacity of a nation should be taken into account. Based on international studies of processes dealing with demobilization and social integration of former war combatants, this research isolated the variables that have been decisive for the success or failure of peacetime adaptation: a) former national experience with the reintegration of war veterans; $b$ ) the nature and consequences of recruitment of future ex-combatants; c) planning by the State and the Armed Forces of procedures for post-bellum demobilization and reintegration; d) the implementation of demobilization and the effects within the military institution and in civil society of the reintegration of former combatants into social and professional life

\section{Learning from the past?}

Former national experiences in war involving the recruitment from civil society of combatants are of prime importance in understanding the types of relationships between veterans and non-combatant society, including the State and the Armed Forces. Society's institutional and collective activities in the demobilization of ex-combatants may or may not be directly based on experiences in former wars. Notwithstanding, nations never discard past experiences, particularly when the latter involved disturbances of the social order or problems with public financing.

Regarding experiences, the USA's past participation in several wars and conflicts constituted a set of collective experiences with demobilization of soldiers, the treatment and re-adaptation of the wounded and handicapped, and the establishment of a system of pensions and benefits for ex-combatants. These processes were conflictive, due the two antagonistic concepts of the national State's activities vis-a-vis the conscripted citizens. The first concept insisted that once conscripted citizens should be rewarded according to their sacrifices. The disruption of their lives involved the removal from the labor force, the loss of education during their formative years and the damage to their physical and mental health. The State should be accountable for the compensation due to veterans. The second concept opposes policies of compensation. In the view of many US citizens, the ex-combatants only did their obligation, a duty to the country and other citizens should not be burdened with 
more taxes or diminished public services caused by the compensation expenses. Underlying this conflict of views, a debate ensued which hailed from the origins of the US as an independent nation, about the far-reaching activities of the State and its power to correct or institute distortions within the country's social and economic relationships. As Theda Skocpol has shown, the pensions for civil war veterans were the first social provisions granted from U.S. national government and the dimensions of those benefits were much bigger than the critics of social protection system would like to admit, at that time and afterwards (SKOCPOL, 1992: 102-105).

In fact, during the post-bellum periods and after each demobilization process, it was customary for the US government to concede a series of benefits to affected citizens. Past history was highly relevant to World War II discussion of the measures that should be taken by the US government and by private entrepreneurs to re-integrate the demobilized troops.

However, a further issue had to be solved. Although everybody agreed on the need to support the social and professional reintegration of war veterans, there was concern that benefits should not create a privileged social group and should not disrupt the principle of equal opportunities for all citizens in society. Budget restrictions and uncertainty about the future made the issue still more complex.

On the other hand, past war experiences had shown that when war veterans were left unaided, as happened with World War I veterans. The Bonus March, a veterans' movement seeking to obtain advance payment of a compensation bonus which Federal Government committed to pay just in 1945, became a turning point of the relationships among veterans, federal government and the whole society. While divided between the acknowledgment of the sacrifices of war veterans and the resistance to establish a privileged group receiving money from the State while the society still faced difficulties, the US population witnessed the repression of the movement and their labeling as potential disorderly (WALLER, 1944: 242-245; WECTER, 1944: 446-453).

Further, former experiences showed that certain social groups, especially immigrants and ethnic communities (Afro-Americans, Japanese-Americans, indigenous) tended towards a recognition of the same rights as other US citizens. By the end of World War I ItalianAmerican immigrants and Negroes had already claimed citizenship as a just reward for fulfilling their duty to the country. However, the claims of Afro-American populations, especially from the Deep South, were rebuffed (SEVERO \& MILFORD, 1990: 231-246).

The debate was resolved with an agreement. Whatever decisions the federal government reached, it must benefit and indemnify those who made huge sacrifices for the country with the aim of making them productive citizens and not a privileged caste forever dependent on the State. Based on this resolution, a system of social veterans of World War II was formulated. 
In its turn, the only large scale Brazilian experience of this kind, prior to World War II, was the reintegration of combatants after the War of the Triple Alliance (1865-1870). The Imperial government stimulated recruitment by promising to donate plots of land to combatants and to provide pensions to wounded soldiers and to their families in case of death in battle. However, when the war was over, few veterans received the benefits and payouts promised (MELLO, 1978: 5-6; BEATTIE, 2001: 38-40; 173-174; SODRÉ, 1978: 143; SCHULTZ, 1994: 73, 75, 91). In a slave and socially stratified society the "tribute of blood" was not regarded as a natural relationship between the State and the civilian turned soldier. This State negligence provoked no revolt or mutinies. Instead there was simply progressive forgetfulness or long waiting and meanderings among bureaucratic offices seeking pensions and medical treatment.

Thus, the Brazilian experience in social reintegration of ex-combatants after the most extensive foreign war was fraught with inefficiency and frustration. Neither the State's structures, nor the elites, nor the Brazilian population as a whole, imagined the combatants as citizens-in-arms, scarifying themselves for their homeland. The tradition of forced recruitment and the general opinion that military service was a punishment, meted out by the State, rather than a service provided by the citizen, contributed towards the perception of the combatants, and, later on, the ex-combatants, as a group of people despised or even feared by the community. In fact, Brazilian society saw them as dangerous and prone to provoking disorders in the streets (BEATTIE, 2001: 78, 172; McCANN, 1982: 21-30).

Seeing a parallel between present and past experiences was not costumary in Brazil. When the Brazilian Expeditionary Force was fighting in Europe no generation of past war veterans put pressure on society or on the State as happened in the US to see that they would be compensated. The more frequent earlier internal armed conflicts generated hosts of veterans but failed to produce any systemic compensatory actions. This was partly due to the negligence of the military commanders. However, it was also caused by the fact that most veterans were military people or people who considered military conscription as an employment and not as an exercise in citizenship. Brazilian military service, precariously regulated between 1884 and 1916 and systemically structured during the 1930s and the 1940s, did not foment in conscripted people a citizenship relationship with the State. On the contrary, between 1937 and 1945 Brazil was under a dictatorship, the so-called "Estado Novo" ("New State"). The classical bases of citizenship such as civil, political and social rights, were either dismissed for all or were conceived as concessions by the State and by the great benefactor, President Getúlio Vargas. In such circumstances, any allusion to the dynamics between rights and duties of citizens and military service would be a mere illusion. 


\section{The recruitment process and the origin of the mobilized soldiers}

The World War I had been a wearying war, characterized by relatively static positions, and frontile soldiers had to be able to run, shoot and dig trenches. In contrast, World War II was a war characterized by mobility and a combination of fire and movement, weapons and technology, which required much more from soldiers than mere physical preparation. War had become a more complex activity and requested different specialties and abilities for combat, besides those related to logistics and communication.

The armed forces of the belligerent countries conscripted men accordingly. Initially the selection processes conscripted the best young men or, at least, the most adequate portion of the population. The process in both countries was superficially similar.

Prior to the US declaration of war on the Axis after the Pearl Harbor attack in December 1941, the mobilization of citizens was determined by the 1940 Selective Service Act which instituted conscription for all young men between 21 and 35 years old, with a 12 to 18 months duration of military service. After Pearl Harbor, military service was extended up until six months after cessation of hostilities and the minimum selection age was lowered to 17 years. Physical and psychological selection was undertaken by the government, employing varied criteria for inducting or rejecting draftees. These facts affected the quality of those selected, specially limiting the numbers available for technical services. The great number of young men who failed the induction examinations was an unpleasant surprise for the military authorities. In fact, $47 \%$ of the first 3 million men examined were below the required standard. Between 1942 and 1943, 12\% or 1,850,000 out of 15 million people examined by the US army (which during the period included also the Air Force) were rejected because psychiatric illnesses and 3,018,000 for physical diseases. Consequently, 4,868,000 or 32.4\% failed the military tests. Even those approved required special care, or rather, approximately 95\% had caries and at least 30\% needed dental treatment. When numbers from the other armed forces are taken into account, 8.2 million out of a total of 22 million young men conscripted (a third) were "unfit in any degree". 2

In spite of these problems, practically all social classes were proportionally represented in war recruitment with no explicit privileges. This huge mobilization discouraged abusive exemptions. The mobilized combatants' profile was proportionate to the population in social origin and schooling. However, when ethnical proportions were brought to the fore, the sampling was slightly less representative. This was partially due to the lack of approval

2 The Health Scandal. The Nation. July 22, 1944, 88. Selective Service in Peacetime. First Report of the Director of Selective Service, 1940-41. Washington DC, Government Print Office, 1942; Selective Service in Wartime. Second Report of the Director of Selective Service, 1941-42. Washington DC, Government Print Office, 1943; Selective Service as the Tide of War Turns. Third Report of the Director of Selective Service, 1943-44. Washington DC, Government Print Office, 1945; FLYNN, 1993:53-87. 
in selection tests and partially due to the exclusion of social relationships which continued during the war even within highly selected troops. Afro-American recruits were segregated in spite of recruitment propaganda targeting not only the white population but also AfroAmericans and Hispanics.

With the addition of mobilized forces, the US army transformed itself from a relatively small military force with few war-making capabilities into fighting force with direct involvement in war. The contrast with the prewar army and the mobilized force is impressive: in 1940 the US armed forces had 266,065 men (16,624 officers and 249,624 soldiers) with only 3 combat divisions. At the end of the war in 1945 there were 90 divisions composed of 8,078,717 men (772,863 officers and 7,305,854 soldiers. When these numbers are added to those mobilized for the US Navy and the National Guards, the total US citizens mobilized may be estimated at 16 million combatants (MARSHALL; ARNOLD; KING, 1947).

The preparation of the mobilization of citizens-soldiers in Brazil for combat abroad occurred several months after the country's declaration of war on the Axis, in August, 1942. The actual involvement started, in the early 1940's, with the provision of strategic materials, iron ore, bauxite, manganese, rubber, quartz crystals, industrial diamonds, coffee, sugar and cocoa for the Allied war efforts.

After the US war declaration against the Axis and the meeting of foreign ministers in Rio de Janeiro at the beginning of 1942, Brazil's involvement included de jure what was being done de facto: the concession of air and naval military bases in the northern and northeastern regions of Brazil to the United States.

After the torpedoing of merchant ships off the Brazilian coast by German submarines, a State of War with Germany and Italy was recognized in August 1942. One month later, the Brazilian government authorized the gradual mobilization of the army. The sending of an armed force to fight Axis was an initiative of the Brazilian government planned to raise an Expeditionary Corps, composed of three divisions, with approximately sixty thousand soldiers (McCANN, 1973: 343-377).

The contrast between what was planned and the real issues was embarrassing. The Brazilian army had just over 95,000 badly armed and ill trained men. The army's plans were to select people among approximately 200,000 conscripted for the three divisions. In July 1943 recruitment for volunteers among 2.4 million young men aged between 21 and 26 years was announced with lots of propaganda ${ }^{3}$. Only 2,750 volunteered, out of whom only 1,570 were deemed fit and able. The medical evaluation process of those recruited was disheartening: medical exams disqualified 23,236 young people out of 107.609 (PAIVA GONÇALVES, 1951: 117-118). Due these results, physical standards were lowered. Reports of

3 BRASIL. Ministério da Guerra. Relatório do Ministério da Guerra, 1943, p. 20; 35-36. 
the selection processes in the various military regions revealed the critical health situation in Brazil, where a high proportion of young people suffered tropical diseases, malnutrition and numberless chronic diseases. The military authorities were tearful of sending the squalid and undernourished Brazilian 'Davids' and the German 'Goliaths'. These fears, however, were unfounded because the hand-t-hand confrontations were not a decisive factor in combat and not all German troops were the Nordic gods as visualized in war propaganda. Moreover, the Brazilians chosen for the future Brazilian Expeditionary Force were not a faithful sampling of public health problems in the country since they constituted units of above-average young Brazilians. (MAXIMIANO \& BONALUME NETO, 2011: 8-9; MAXIMIANO, 2010: 54-63).

However, as recruitment results were being published, hundreds of exemption petitions were being forwarded, especially by those with advanced schooling, who enjoyed political and military 'godfathers'. Exemptions were awarded for various reasons such as young men being the only sustenance of a family, being married condition, or being civil servants whose jobs were considered of national interest, and having a brother of already conscripted. Such exemptions reduced the number of those drafted. Even within the Brazilian Army, many authorities were against the sending of the expeditionary troops (FERREIRA JUNIOR, 2007: 17-19). Finally, all these factors provided a new configuration to the expeditionary force which was reduced to a single army division, or rather, composed of soldiers, mostly young people from the urban and rural working classes, with little schooling, commanded by regular and reserve officers.

The consequences of the conscripted soldiers' social origins and level of schooling became evident in the social and professional reintegration of the ex-combatants. The provision of university and technical schooling for veterans in the US reached eight million veterans. Studies show that after two decades from the end of the war US veterans of World War II earned, on average, more than their contemporary non-combatant colleagues. This difference was perhaps due to the initial selection that placed young people within the US armed forces with a higher schooling than that of the average of people who were dispensed from military service. The young people who returned home benefitted more from the set of legal privileges related to the social reintegration of war veterans (ANGRIST, 1989).

Although physically more robust and with average schooling higher than the noncombatant population, Brazilian veterans perceived that their rights and benefits were regulated according to the same social relationships of exclusion practiced before the war. The upper and middle classes, with better schooling and excellent social relationships (with good political and economic contacts) had easy access to eventual benefits. However, most expeditionary troops had to cope with more difficulties even when they appealed to veteran associations. Participation in the war failed to guarantee equal opportunities. On the contrary, the chances that the young war veterans who expected that their absence from the 
labor market and from professional formation would be compensated by their military activities found that their social class and educational level were more important than their status of veteran. Since such men had a low level of schooling and no powerful 'godfathers', they had difficulties obtaining the legal benefits due to veterans.

\section{Impacts of mobilization}

The recruitment of young citizens for military service during their productive years caused changes in both American and Brazilian societies and their military institutions.

Mobilization for war deeply affected US society because a war-directed economy increased the number of jobs from 46 to 53 million. Owing to the displacement of 16 million young men during their most productive years to the Armed Forces, job vacancies were plentiful. Moreover, not only were unemployed males replacing those people who went into the military, job opportunities were given to females and social groups, such as AfroAmericans, Hispanics and First Nations, who previously had employment difficulties in certain labor areas. During the war the social and cultural mobilization promoted the image of a just war and a good fight, which, after the war, was transformed into the image of "the good war". The wide approval of the war effort and its attendant sacrifices provided a favorable and a welcoming environment for the demobilization of veterans who returned to their homes, jobs and schools (JEFFRIES, 1996: 16-42, 93-119; ROSE, 2008, 225-250; WYNN, 1996).

For Brazilians, war was a distant occurrence even after its declaration. The war economy caused rationing of food supplies and fuel, extra hours were required from urban workers in the 'Battle for Production', the newspapers daily reported news of Brazilians on the front. However, the small dimension of the Brazilian Force, when compared to the country's population, diluted the drama of direct war involvement for many people. The families of the Expeditionary Force. Whereas in the United States more than $10 \%$ percent of the population was directly involved in the war, the 25,000 Brazilian soldiers were only $0.06 \%$ of the entire population. If practically every American family had at least one person in combat, the Brazilian families concerned with the fate of their young people on the front were relatively few.

The most visible of the impacts on Brazilians were political. The contradiction between fighting Nazi-Fascism and having an authoritarian regime at home was extremely evident and produced deep political consequences. During the last weeks of the war in Europe, the end of the Vargas dictatorship was already on the agenda of the opposition and even of the government. 
Such disrupting contradictions were not the exclusive conditions of the Brazilian regime. Negro US soldiers also perceived the contradiction in fighting a racist Nazism and experiencing racial segregation within their country's army as well as at home. The $92^{\text {nd }}$ Division of the US army, also called the 'Colored Division' or 'Buffalo Soldiers', composed exclusively of Negro soldiers commanded by white officers, had fought close to the Brazilian units in Italy. Moreover, there were other segregated units in the US armed forces. The contrast was extremely evident since the Brazilian Army was, in racial terms, the only integrated unit in World War II (ROSENHECK, 2010; MAXIMIANO \& OLIVEIRA, 2001: 155182).

However, one of the most significant consequences of mobilization occurred in the interpersonal relationships of the armed forces. The armed forces which had been structured in peacetime for the formation and training of officers and professional soldiers and civilian recruits had such strict hierarchical practices between superiors and subalterns that soldiers in the lower ranks suffered constant humiliation. The aim was to demonstrate who gave orders and who had to obey them. Such social relationships, typical of military structures of the 1940s, existed regardless of country and its peacetime recruiting regime. However, mobilization and the war changed all this. The admittance of millions of reserve soldiers and officers from the civil milieu caused deep social in the armed forces. Hierarchic relationships were gradually molded more on efficaciousness in combat than on the humiliation of soldiers. War's dynamics enhanced transformations in internal relationships among the combatants, without any damage to hierarchy and discipline. It was a war involving citizen-soldiers, defined by them and fought by them (MCCANN \& FERRAZ, 2013: 115-122; MAXIMIANO, 2010: 359-379).

The military authorities of both countries were aware of such changes, although their attitudes toward reshaping the armed forces were highly different. In the US, the transformations of the military institution were seen as unavoidable after the admission of so many civilians into the army. Understanding the reach of such changes and the obtaining higher combat efficiency were required. The Army's Research Branch studied the soldiers' feeling with regard to combat, their superiors, the war, the home front and their perspectives on return to civil life. A motivated soldier would fight better than a disheartened one and would later cause fewer problems at home ${ }^{4}$.

4 STOUFFER, 1949: 27-29. In 1947, it was developed an investigation about several complains from enlisted personnel against authority abuses practiced by officers. This investigation was made by the Secretary of War's Board on OfficerEnlisted Man Relationships. The Board researched letters, documents, made interviews and produced a document, known as "Doolittle Board Report". This document recommended to cut off the excess of authority in order to increase efficiency in combat. In spite of have generated acid criticism among regular military officers, several recommendations from this Report were applied. Officer-Enlisted Man Relationships. Report of Secretary of War's Board on Officer-Enlisted Man Relationships to Hon. Robert P. Paterson, The Secretary of War. May 27, 1946. U.S. Senate. Document n. 196, Washington D.C.: United States Printing Office, 1946; SPINDLER, 1951: 305-310. 
The majority of the Brazilian military was not fighting in Italy but was on duty in its own country. Besides not been alert to the changes in disciplinary habits learned during the war, which were very different from those in the Brazilian military, concern existed that those who had gone to Italy receive more promotions and prestige than those who remained in Brazil. The officers and soldiers of the Expeditionary force would soon discover that on their return to their country they would not be welcomed by those at home, as they had expected.

\section{The planning of demobilization and its execution}

Allied demobilization started as soon as war ended in Europe on the $8^{\text {th }}$ May 1945 . The bitter experience of demobilization process and of the social and professional reintegration in the US after World War I had not been forgotten. Without a systemized set of protective laws dealing with employment re-insertion and job opportunities, the 4.7 million veterans of the 1914-18 War had to fend for themselves and fought for jobs and opportunities with those who had stayed at home. Their protests and demands caused the federal government in 1924 to offer a money bonus which would be received in 20 years. These movements gave the civilian population totally unprepared to receive them, an image of the veteran soldier as a disgruntled person waiting for government relief. After the 1929 crisis the Great Depression became extremely painful to bear, and so the World War I veterans tried to obtain their bonus before its maturity. The so called Bonus March was violently crushed by the Hoover administration in 1932 (DICKSON \& ALLEN, 2004).

Due to that unfortunate experience, the demobilization of World War II veterans was on the minds of the government, officials, politicians and entrepreneurs. Beside the question of how to compensate for the years the veterans had been outside the labor market and how to re-integrate all those physically and emotionally changed by the war, there was the need to shift from a war to peacetime economy. The number of job openings would lessen drastically at exactly the time when the veterans would anxiously return home to resume their lives, their social lives and their professions.

The US War Department ordered studies on the best demobilization methods for its millions of citizen-soldiers. Many issues had to be accounted for: military issues (which units or groups could be demobilized first without jeopardizing the occupation of whole countries in Europe and the campaign on the Pacific Front); logistic issues (the number of ships available for the return of the demobilized troops without jeopardizing the on-going war, and the amount of money needed for muster-out pay); social and political issues (the manner the ex-combatants would be received, to meet their needs and to avoid mass 
unemployment). Hundreds of research work and studies were undertaken by the armed forces, universities and state legislatures to provide solutions.

The most important result from such work was the Servicemen's Readjustment Act (1944), commonly known as G.I. Bill of Rights, which provided educational and economical benefits to war veterans. The Servicemen's Readjustment Act was signed by Roosevelt on the $22^{\text {nd }}$ June 1944 and conceded benefits to all veterans with more than 90 days of active military service and without any kind of criminal records: a) US\$ 20 a week during 52 weeks at the most, as long as the ex-combatant remained unemployed (The 52-20 club $^{5}$ ); b) scholarships in universities or in professional courses that covered fees and cost of books; c) a warrant from the government to borrow money to finance purchases of houses, farms and small enterprises; d) government coverage of hospital charges; e) the establishment of a government agency for veterans seeking jobs; $f$ ) a guaranteed return to the same job as held before the war; the employers was prohibited to fire the veteran for a determined period.

As all projects under development, the Servicemen's Readjustment Act had its ups and downs. When read in Congress, representatives of the Southern states objected that parts of the Bill benefitted equally black and white veterans. However, the law guaranteeing the rights of veterans was passed, although its implementation was far more difficult than expected. Its positive impact favored fewer negro veterans and women who faced restrictions. Other problems arose when the law was applied. It was not easy for nonveterans to enter universities since the latter were already quickly filled with veterans. Tensions unforeseen by lawmakers were rife since the theoretically equal opportunities principle, one of the most basic principles in US democracy, was hit. Many civilians were of the opinion that veterans were being treated as a privileged group, leaving the rest of the population to dispute what remained of the nation's wealth and opportunities (MAULDIN, 1947: 110-11; ROSE, 2008: 235-241).

A number of pamphlets, handbooks, books, film advertisements and radio programs tried to explain matters to civil society so it would understand how to welcome the war veterans. Later more was published to demonstrate the problems veterans faced and to emphasize that the reintegration was not so smooth and easy.

Since demobilization was planned at the same time as laws on veterans were enacted, it was structured to give homecoming priority to those who had served the country for more time and in the most dangerous and risky situations and to those whose family situation required their immediate and urgent return. A system of accumulated points was adopted in which mobilization duration, service time outside the US, combat activities and the number of less than 18-year olds in the family were taken into account.

5 The buying power of US $\$ 20$ in 1944 would be equivalent to US\$267,87 in April 2014 . Cf. http://www.dollartimes.com/calculators/inflation.htm 
Even though planning was foremost, delay in demobilization caused bitter protests not only in the USA but also in the units waiting for repatriation orders. The number of ships was insufficient and even though the monthly rate of repatriation reached hundreds of thousands of soldiers, neither the population nor the mobilized soldiers considered it as sufficiently swift. The problem became more drastic when Japan was defeated. To make matters worse, the armed forces perceived the need to maintain troops in occupied territory and so everyone could not be demobilized at a very early date. With the exception of recently-engaged troops, whose task was to pacify and keep order in occupied territory, the great majority of troops returned home by the end of $1946 .{ }^{6}$

The aftermath of the planned demobilization and reintegration soon appeared at the short and medium term. In addition to millions of young people frequenting technical and high school, funding provided a boom in house building and in the establishment of small enterprises and shops. Recent studies show that the people of the Greatest Generation who fought in World War II had the highest rates of political participation and involvement in community issues when compared with former or later generations of war veterans (METTLER, 2002; METTLER 2005).

These benefits, however, were not for all. Negro veterans, especially from the southern US often had their rights trodden on. Although they had their discharge papers, they had to face the unwillingness of bank managers and tribulations in segregated higher education institutions. Female, homosexual and American Indian veterans frequently also had their rights denied. Although the original intention was the transformation of the veteran from a mere recipient of government benefits into a new citizen whose experience mobilization would encourage him to be more productive and to participate more actively in society (ONKST, 1998; BROOKS, 2004; CANNADAY, 2003: 935-957; FERRAZ, 2008: 480-481.

Seen from the above perspective, the demobilization of Brazilian troops from the Mediterranean Theater of Operations would be less problematic. In contrast to the US millions, Brazil had a mere 25,000 ex-combatants to demobilize and re-integrate and the reconversion of the country's economic structure for peace time did not exist. Moreover, the lessons of success and the problems of past mobilizations experienced by the Allies could have been adopted and procedures could have been imitated or, at least, they could have served as an example. Unfortunately, nothing of this kind took place. Neither the lessons of Brazil's last foreign war, the Triple Alliance War, nor the activities of their allies in Europe were analyzed or taken into consideration(FERRAZ, 2012: 106-109).

6 University of Tennessee Governmental Reference Service. Homefront planning for the postwar period. a symposium on postwar problems of Tennessee and the nation. University of Tennessee (Knoxville campus). Bureau of Public Administration. Knoxville, Tenn., The University of Tennessee Governmental Reference Service, 1944; SPARROW, 1952: 219-220; BALLARD, 1983: 73-116. 
Curiously enough the US military, directly linked to the Brazilian Expeditionary Force, were concerned about the demobilization in the South American country and suggested better use for the mobilized troops after the war. ${ }^{7}$ Suggestions were made to the Brazilian authorities. In fact, there must have occurred an exchange of information on a possible shifty demobilization of the Brazilian Expeditionary Force. A documentary investigation on the subject showed that the Brazilian Ministry of War was prepared to undertake a type of demobilization similar to that planned by the US army for its soldiers. The four studies published between May and June 1945 included logistic provisions of transportation of Brazilian veterans with regard to discharge, homecoming festivities and even suggestions for utilizing the professional framework of the expeditionary force in the future development of the Brazilian army ${ }^{8}$.

However, were such considerations limited to military personnel. Because the Brazilian Expeditionary Force was not a regular part of the army but mostly formed on citizensoldiers, the latter would return to civil activities when demobilized. The non-military characteristics of demobilization were never taken into account. The expeditionary troops, their families and the civilian society were not prepared for their return. Fundamental and necessary regulations, such as attention to handicapped veterans, were only provided for a number of months after the troops returned to Brazil.

Moreover, whereas certain officers were concerned with planning the utilization of the demobilized troops within the army, top authorities of the Ministry of War took an opposite direction which was more in line with civil policies. The Ministry of War published orders on demobilization and the dissolution of the Brazilian Expeditionary Force when it was still on foreign soil, and placed the expeditionary unit under the authority of the Military Commander of the Rio de Janeiro district which then was the capital of Brazil. On their return the troops were not only prohibited from commenting on the Italian Campaign but their uniforms could not be worn after 8 days. Such restrictions may be explained by the Brazilian political situation at that time. In fact, intense discussions occurred over the ending of Vargas's Estado Novo between opposition and others who wanted him to remain in office. The army was wary of a possible liaison between communists and Vargas and many strategies to lessen the political impact of the Brazilian Expeditionary Force were employed. The quick and hushed demobilization of the Brazilian troops avoided the political use of the Brazilian Expeditionary Force within the contemporary Brazilian situation (FERRAZ, 2012: 126-137).

7 OPD 336.2 Brazil - Demobilization of the Expeditionary Force 6 apr 45 - Secret. Records of the War Department, Washington, apudFARIAS, 1981: 661.

8 E.M./F.E.B./I(Estado-Maior da FEB no Interior). Instruções a Evacuados, Isolados ou em Grupos. Rio de Janeiro, 02 maio 1945; Portaria No 8.250 do Ministério da Guerra. Diário Oficial da União em 11 de maio de 1945); E.M./F.E.B./I. Proposta de Instruções para Desmobilização das Unidades da FEB, Rio de Janeiro, maio 1945; E.M./F.E.B./I. Destino das Unidades da FEB (Apreciações sobre as sugestões do E. M. E.). Rio de Janeiro, 04 jun 1945; E.M./F.E.B./I. Instruções, regulando o destino dos oficiais da FEB pertencentes aos Quadros das Armas e dos Serviços de Saúde e Intendência, jun 1945. Arquivo Histórico do Exército, Arquivo Depósito de Pessoal, Cx. 522, Arm. Nº17. 
The social consequences of such a swift demobilization were disastrous and lasted a long time. Festivities and homage to veterans, which turned out to be the greatest in Brazilian republican history, gave them the illusion that a thankful homeland would not fail them, in their needs. The civilian society's reception of the war veterans went beyond mere festivities and homage. In the veterans' opinion, they were returning to daily peacetime routine.

Their first challenge was to re-establish their social lives. However, after witnessing the barbarian turmoil of war, it was soon evident that they would not be the same. Months living far from their families, in an extremely different social environment, and sharing other values, made them different people. A wide chasm existed, between their present state and the people they were before conscription. Further, contrary to what occurred with U.S. ex-combatants, the Brazilian Army did not provide any support or help so that Brazilian war veterans would successfully return to civil life. Civil society was poorly prepared to understand the adjustment difficulties of the war veterans. Owing to the relatively insignificant number of veterans, in proportion to the Brazilian population, it was expected that they would adapt themselves to society and not the other way round (SILVEIRA, 1989: 235; FERRAZ, 2012, 162).

During the first weeks after on their return to Brazil, practically all the ex-combatants, as a rule, had some difficulty in living with the civilian population. Greater chances for reintegration existed for schooling or professional jobs. However, most veterans found it difficult to adapt themselves successfully, to routine civil life. These concerns were deepened by the civil population's assumptions that all war veterans were potentially neurotic. Cases of alcoholism and domestic violence deepened re-socialization problems and increased the veterans' marginalization. The Brazilian press frequently reported cases of ex-combatants living in dire poverty on the streets of the large cities, and of others committing suicide, even some years after the war (BARCELLOS, 1965: 143-161; SOARES, 1985: 16-17, 20-23, 341-344; SILVEIRA, 1989: 244-246).

Difficulties in sharing with the community their remembrances of war, attempted by the veterans, were equally problematic. People avoided listening to war veterans and their war stories. To make matters worse, ex-combatants frequently were told that, what they did in Italy was a mere excursion, not a real war. Devaluing their saga and sacrifices in combat piled heavily on their material concerns.

A relationship between the rate of social mobilization for war and of successful social reintegration may be established. The higher the rate of society's mobilization, the more successful the veterans' social and professional reintegration would be. Although Brazilian society supported its young people, when they departed for the battlefield, on their return, in the wake of festivities, the true effects of war on Brazilian society were as low, as the proportion of combatants within the whole Brazilian population. The United States, 
featuring the highest reintegration of World War II veterans in the Western world, could count an expressive parcel of its male adult population as veterans. Practically every large U.S. family had, at least, a member in the war and consequently a veteran. They just couldn't avoid the problem of homecoming. On the other hand, when U.S. young people went to Vietnam, its society was divided between those who supported and those who condemned the war. Mobilization was lower in proportion to the total adult male population. The Vietnam War veterans, albeit featuring a more advanced legislation than that of World War II, failed to have the same success in social reintegration. It was actually not "a good war" (PIEHLER, 1995: 126-153; WYNN, 1996; SEVERO \& MILFORD, 1990; TERKEL, 1984)”9.

Lack of experience with regard to a national mobilization for war, and to a comprehension of the veterans' problems, worsened the reintegration of Brazilian veterans in their respective professions. Conscription laws guaranteed a return to the same jobs they had left. However, the laws were overridden. Even when they were followed, in most cases, war veterans were dismissed after starting, with the allegation that they could not adapt, were incompetent and could not relate. Further, the right to be readmitted to the former job applied only to city workers, since rural workers had absolutely no rights in the 1940s. Because most people worked on farms and plantations, and the FEB represented the country's working class, a significant number of war veterans found themselves without any rights on their return ${ }^{10}$.

War veterans with any type of disease, such as respiratory complications acquired on the front, or disability due to war wounds, had to wait for months and even years to file for indemnity and pensions. They were highly uncertain whether they would receive social benefits, since government officers treated them with distrust, and always suspected them of fraud and simulating non-existent diseases. The pattern repeated itself frequently: the schooled and better connected people received the social benefits, whereas most had to wait a long time to have their due and, even in this case, not always successfully (SILVEIRA, 1989: 244; FERRAZ, 2012: 184-188).

Leaders of veteran associations filed benefit projects, similar to those forwarded to the U.S. government, but were unsuccessful. Although they were brothers-in-arms during the war, their post-bellum fate was highly different.

9 In United States, World War II veterans and civilian people were previously prepared to the demobilization. Books as "Counseling with returned servicemen"; "Problems of the Post-War World"; "Soldier to Civilians: problems of readjustment"; "Good-by to G.I. - how to be a successful civilian", "When Johnny Comes Marching Home", "The Veteran Comes Back", and newsreels as "Welcome Home", "The Returning Veteran", "Peace Comes to America" "He Has Seen the War" had been produced to make the veterans readjustment easier. Cf. Veterans' Information Program. Washington, DC, Records of Office of War information, February, 1945 (National Archives and Records Administration, College Park, MD (NARA-CP), RG 208, Box 5; Project “When I Come Home” (NARA-CP, RG 208, box 1534); Veterans' Administration Pamphlets (National Archives and Records Administration, Washington, DC, RG 15, boxes 3 and 4); See also COLE, 1978, 41-61; HARTMANN, 1978: 223-239; HUEBNER, 2008, 26-28; ROSE, 2008: 229-235.

10 Anais da Câmara dos Deputados. Rio de Janeiro, Vol. VII, 55 Sessao, 4 dez 1946, p.04-07. 


\section{The veterans' political organization and participation}

Tense relationships between civil citizen-soldiers and the Brazilian state, responsible for their conscription, selection, training, maintenance and discharge reappeared with double strength as soon as the veterans started to re-integrate themselves within society. After the wars waged in the previous century by the United States, associations of veterans were established to claim rights and benefits to which they thought they had a right. When World War II started, two associations emerged in the name of war veterans and their rights. The large and conservative American Legion (AL) and the also conservative, albeit with challenging motifs within the country's political standards, Veterans of Foreign Wars (VFW), tended to collaborate with the administrations and obtain assets for war veterans through the concession of more benefits.

Although the two associations saw their flanks bulging with large contingencies of 'fresh' veterans after the end of the war, many veterans, especially those from the more liberal layers (from the US point of view), felt annoyed at the political traditionalism and the xenophobic nationalism of the AL and the VFW, and formed two new associations. Initially the American Veterans Committee (AVC) and the American Veterans of World War II (AMVETS) gathered only combatants of World War II. Although the latter association criticized the political practices of its predecessors, it gradually shifted toward a politics of social assistance. On the other hand, the former was more aggressive and less conservative than all the other veteran associations in the US. AVC determinately opposed the exclusive demands of the other associations for benefits and advantages since it was convinced that the struggle for this counterpart was just only one of the activities that could be achieved by the veterans in the postwar. Since they had defended democracy and the politics of the national State on the war front, they felt that they had not only the right but the duty to participate in the social and political conditions for which they had risked their lives. War veterans would be more than mere passive receivers of advantages due to their participation in the war. It was also their duty to fight for peace within and outside the country's frontier and to guarantee liberty and equal rights for all. With their motto Citizens First, Veterans Second, they were the sole US association of war veterans to frontally oppose neocolonialism, gender and racial discrimination, and support the establishment of the United Nations. In fact, the chasm between the AVC and the other associations was so wide that it drew the attention of the opposition and the political surveillance of conservative Congressmen who were anxious to witch-hunt communists within the association. Actually there were Communist Party members within its flanks and among its top officers. Although the AVC discharged Party members, it was persecuted by McCarthyism and 
gradually lost many members and the appeals of its liberal policies and political strength dwindled away (SAXE, 2007: 117-153; HOEFER, 2010).

An analogous process occurred in Brazil. The first associations of ex-combatants were established immediately after their return to Brazil. The national association called Association of Ex-Combatants of Brazil (AECB) gathered members from all political groups. However, the better organized communist veterans gradually started to lead the AECB's public activities and discourses and became a constant concern to anticommunist groups, especially those inside the Brazilian army. The AECB was highly aggressive in the vindication of veterans' rights and public manifestations were organized against the neglect of the administration towards the veterans. Moreover, it defended the right of the veterans to actively participate in the current political debates. Their motto recalled that of AVC: "More than a Veteran, a Citizen". Similar to the AVC, pressures to discharge communist leaders from the AECB were intense until their final expulsion from the association. When the association was purged of its leftist leaders, its activities concentrated on the defense of veterans' rights by collaborating with the administration and the Army and by avoiding any friction with the authorities. Although another association exclusively for the Italian Campaign veterans (which excluded those mobilized for coastal defense) was also established, it copied the political practices of the AECB. As had happened in the US, most Brazilian veterans, therefore, preferred a more conservative policy and avoided any conflicts with the government and the National Congress.

\section{Reflections on the two demobilization and social integration experiences of war veterans}

This analysis of the American and Brazilian types of mobilization and social integration processes produced a differential common experience with regard to success and failure in both countries, or rather, the different modes citizenship was exercised and they affected the procedures and results of the binomial demobilization-social integration. This examination of the mobilization of civilians for war was understood to be a requirement of the National State which, as compensation, would provide these citizens with the means both for combat and for family assistance. Consequently, the demobilization and social and professional reintegration of veterans would be the outcome of the process.

In fact, it is one of the fields which in Brazil should be deeply explored by historians since the existing research is scanty. Interest on the subject by historians has increased in the last five years. As may be expected when the "new" themes are explored, research has focused on unpublished documental sources - military records and files of veteran associations, newspaper articles, oral history, studies of the FEB monuments, documentary 
and commercial films, songs of the campaign. It is highly probable that in the near future more critical debate will probe deeper and produce useful interpretations of demobilization and social integration.

The US has already a traditional historical and 'canonical' version on the social reintegration of its war veterans. With slight variations it is a history of success narrating how the US emerged from World War II as the dominant capitalist nation, with all its citizens sharing general prosperity and its war veterans, their families and friends, as agents of the process. The Greatest Generation is actually the theme of numerous books, films, documentary film, memorials, shows and homage. The narrative of this generation's achievements was prefaced by the difficult Depression period of the 1930s, the war against the Axis, the hard-won victory and, consequently, the construction of the bases of economic prosperity and of US policy. It is the differential factor with regard to latter American generations accustomed to the comfort inherited from the amazing generation that came before them. On the one hand, it is the narrative of the trajectory of millions of war veterans welded to that of the civilian society, on the other (ROSS, 1969; OLSON, 1974; GREENBERG, 1997; BENNETT, 2000; VAN ELLS, 2001; GAMBONE, 2005; METTLER, 2005; HUMES, , 2006; ALTSCHULER \& BLUMIN, 2009).

The historiography of the social reintegration of World War veterans in United States has been thus molded by such a perception of collective memory. Both the liberal (reintegration as an example of a successful government intervention regarding a social problem that contributed to the construction of the American welfare state) and the conservative version (according to which the decentralized traits of reintegration produced neither dependent clients nor any powerful bureaucracy) revealed a balanced process, not without certain problems, which was highly positive and exemplary for later generations. Until the 1980s the historical interpretation was overflowing with praises and showed how much contemporary generations owed to those who fought in the war and worked on the home front in the structuring of economic prosperity and in the social and political improvement thanks to the civil rights movements. However, in such narrative of historical success, it is not mentioned the resistance of some political and social groups against the economic reintegration of veterans. One of these groups was southern segregationists. Another was political conservative groups, who suspected of the excessive power conferred to the Federal government in the post-war period. (FRYDL, 2009: 7-35; SAXE, 2007; BROOKS, 1994).

Therefore, in the mid-1990s fends and fissures within that romantic historical version began to appear. From the Deep South (Alabama, Georgia, Louisiana, Mississippi and South Carolina) came the challenges to the reintegration of African-Americans, whose rights were denied. Studies on this issue tended to link the struggle of Afro-American veterans for 
equality with regard to promised benefits to the beginnings of the civil rights movements (ONKST, 1998; BROOKS, 2004; SAXE, 2007).

Female war veterans were also the object of several studies. The veterans of female units with their hundreds of thousands of volunteer women (who did important war services) were discarded in the social reintegration process and several rights listed in the G.I. Bill of Rights were denied them. Rights were also denied to veterans that were activists who fought against racial discrimination and homosexuals. These two categories were "dismissed with dishonor", alongside other dismissed in this same category, as thieves, murderers and rapists. (BÉRUBÉ, 1990: 228-243).

Some historians concentrated on a group of veterans who, although covered by the reintegration laws, were heavily penalized in the post-war period. These were the psychological misfits. They were statistically included within the G.I Bill rolls. The mere statistics, however, failed to show the growing disadjustment between these veterans and the civilian society. It is only recently that these marginalized people are receiving some attention from historians ${ }^{11}$. The category varied widely throughout the post-war period since many disturbances appeared only decades afterwards. Most psychiatric problems occurred with frontline combatants, who were affected by the barbarities of the combat. Since a great portion of veterans (between 20 and 25\%) who received benefits did not even leave the country, and since only $1 / 4$ out of the remaining $3 / 4$ experienced real combat, the proportion of veterans suffering from psychic disorders was actually bewildering. In fact, in the aftermath of the war, more than half of the psychologists and psychiatrists in the US were at the service of the armed forces due to the great number of cases needing treatment.

Besides the focus on the group of veterans who were not benefitted by the grand success of the G.I. Bill and its social reintegration policies, the real application of the Bill was also heavily criticized. One of the successful amendments of conservative congressmen and senators when the war veteran reintegration bill was passed, comprised the decentralizing character of its application. Although the financial resources came from the federal government, their distribution was the duty of state and county authorities. High indexes of corruption and misappropriation were reported. Almost one third of the funds applied in higher and technical education were addressed to phony institutions. The unemployment benefits (The 52-20 Club) also showed high embezzlement levels (FRYDL, 2009, chaps. 3,4 and 6).

The tensions and conflicts between veterans and civilian society, hidden under the carpet by traditional historiography, were recently brought to light. From the veteran's point of view, US society failed to honor their sacrifices on the front, whereas for the people at home the veterans did not have any idea of the sacrifices which civil society was forced to

11 CHILDERS, 2009. What is highly important is the fact that, on the veteran's return, the problem was already known and discussed by the health services personnel of the armed forces. Cf. PRATT, 1944; GRINKER \& SPIEGEL, 1945. 
bear during the war. These tensions had been acknowledged during the war and several civilian and military departments tried to make them known, to remove them from focus or to mitigate them before and during the veterans' reintegration process. Hosts of scholarly works, handbooks, self-help books, films, documentaries, radio programs, articles in magazines and newspapers were published to smooth the relationship. The "veteran problem", as it was called in the immediate postwar years, concerned several social groups and show how complex it was for American society to manage the issue. However, in spite of so many acknowledged conflicts, up to recent decades, hegemonic historiography portrayed the veterans' re-socialization as highly successful, with only a few cases of failure. It was only recently that historians have devoted themselves to put in doubt the unresolved issues in this matter.

Thus, instead of complying with the praiseworthy aspects of the veterans' social lives and that of post-war society, historians are beginning to scrutinized the archival materials produced and, consequently, a different version of the social integration will be forthcoming. It should be emphasized, however, that there will be no simple inversion in the interpretation of the US post-World War II interpretation from success to failure. In general terms, the social reintegration of World War II veterans is still a landmark in transformation which decisively contributed towards the molding of the country. However, the interpretation from the recent re-examination provides a more complex account and even a contradictory narrative of the historical process. The tensions revealed, the problems faced and the solutions found or delayed produce a more chaotic picture, albeit more complex and precise, of the events closely linked to the universal themes in the study of historical processes such as that discussed above which include citizenship, the activities of the National State, the political organization of war veterans, the armed forces and the relationship between war and society.

Therefore, comparing these two processes of veterans' social integration, one shared experience arises as the decisive variable concerning successes and failures of the two countries: the different ways in which citizenship was experienced affected the processes and results of reintegration. In this study, the mobilization of civilian citizens for the war was understood as a requirement of the National State, which in turn was obligated to provide these citizens both the means to fight and assistance to their families.

Thus, the demobilization of citizen-soldiers and the measures to reintegrate them would be the result of this process. In the United States, the principle that guided the process was to avoid having citizens dependent upon government benefits and to stimulate citizens to be economically productive and an active participants in the community. However, some social groups were "lesser citizens" than others, as was the case of the black veterans in the South of the country, and also women and minority veterans, who encountered obstacles to obtaining their GI Bill benefits. 
This latter situation resembled the experience of Brazilian veterans, who had legal rights, but could not obtain the benefits. However, there was one important difference: the servicemen's benefits received from the Brazilian Government were perceived by veterans and by the civilian population to be more like a concession or a favor from the Government, than a right acquired through the payment of the "tribute of blood". All these similarities and differences are keys to understanding the two political cultures concerning civil and political rights, as well as the social policies of the two governments.

\section{Bibliography}

ALTSCHULER, Glen C.; BLUMIN, Stuart M. The G.I.Bill: a New Deal for Veterans. Oxford: Oxford University Press, 2009.

ANGRIST, Joshua. Why Do World War II Veterans Earn More Than Nonveterans? Princeton, NJ, Working Paper 254, Industrial Relations Section, 1989.

BALLARD, James Stokes. The Schock of Peace: Military and Economic Demobilization after World War II. Washington D.C.: University Press of America, 1983.

BARCELLOS, Luciano Alfredo. "A flagelação dos ex-combatentes". In: Louzeiro, José (org.). Assim marcha a família. Onze dramáticos flagrantes da sociedade cristã e democrática, no ano do IV Centenário da cidade do Rio de Janeiro. Rio de Janeiro: Civilização Brasileira, 1965.

BEATTIE, Peter. The tribute of bood: Army, honor, race and nation in Brazil (1864-1945). Durhan: Duke University Press, 2001.

BENNETT, Michael. When the Dreams Came True. The G. I. Bill and the Making of Modern America. Washington: Brassey's, 2000.

BÉRUBÉ, Allan. Coming Out Under Fire: the history of gay men and women in World War II. New York: The Free Press, 1990.

BROOKS, Jennifer E. Defining the Peace: World War II veterans, race, and the remaking of Southern political tradition. Chapel Hill: University of North Carolina Press, 2004.

CANADAY, Margot. Building a Straight State: sexuality and citizenship under the 1944 G.I. Bill. Journal of American History, vol. 90, n. 03, p. 935-957, December, 2003. 
CHILDERS, Thomas. Soldier from the war returning: the Greatest Generation's troubled homecoming from World War II. Boston: HoughtonMifflin Harcourt, 2009.

COLE, Garold. Home from the War: the popular press views the veteran problem, 1944-48. The North Dakota Quarterly. Summer 1978, 41-61.

DICKSON, Paul; ALLEN, Thomas B. The Bonus Army: an American Epic. New York: Walker and Company, 2004.

FARIAS, Osvaldo Cordeiro de. Meio século de combate: diálogo com Cordeiro de Farias, Aspásia Camargo, Walder de Goes. Rio de Janeiro: Nova Fronteira, 1981.

FERRAZ, Francisco Cesar Alves. A Guerra que não acabou: a reintegração social dos veteranos da Força expedicionária Brasileira (1945-2000). Londrina: EDUEL, 2012.

As Guerras Mundiais e seus Veteranos: uma análise comparativa. Revista Brasileira de História. Vol. 28, n.56, 2008.

FERREIRA JUNIOR, Alcemar. Uma visceral rebeldia: clientelismo e isenções no recrutamento da Força Expedicionária Brasileira (1943-1944). In: SANTOS, Cláudia R. Andrade dos (et al.). Estudos - vol. II - Série Grupo de Pesquisa LEPH/Programa de Mestrado em História Social/Universidade Severino Sombra . Curitiba, 2007.

FLYNN, George Q. The Draft, 1940-1973. Lawrence: University Press of Kansas, 1993.

FRYDL, Kathleen J. The GI Bill. New York: Cambridge University Press, 2009.

GAMBONE, Michael D. The Greatest Generation Comes Home: the Veteran and the American Society. College Station: Texas A\&M University Press, 2005.

GREENBERG, Milton. The G. I. Bill: the law that changed the America. New York: Lickle Pub Inc., 1997.

GRINKER, Jr., Roy R.; SPIEGEL, John P. Men Under Stress. York, PA: Blakiston Company, 1945.

HARTMANN, Susan M. Prescriptions for Penelope: literature on women's obligations to returning World War II veterans. Women's Studies. Vol 5, 1978, pp 223-239.

HOEFER, Peter D. A David against Goliath: the American Veterans Committee's challenge to the America Legion in the 50's. PhD Dissertation. Department of History, College Park: University of Maryland, 2010. 
HUEBNER, Andrew J. The Warrior Image. Soldiers in American Culture from the Second World War to the Vietnan Era Chapel Hill: The University of North Carolina Press, 2008.

HUMES, Edward. Over There: how the G.I. Bill transformed the American Dream. Orlando: Harcourt, 2006

JEFFRIES, John W. Wartime America: the World War II Home Front. Chicago: Ivan R. Dee, 1996.

MARSHALL, George; ARNOLD, H.H.; KING, Ernest. The War Reports of General of The Army George C. Marshall; General of the Army H.H. Arnold; Fleet Admiral Ernest J. King. Philapelphia \& New York: J.B. Lippincott Company, 1947

MAULDIN, Bill. Back Home. New York: William Sloane Associates, 1947.

MAXIMIANO, Cesar Campiani. Barbudos, sujos e fatigados: soldados brasileiros na Segunda Guerra Mundial. São Paulo: Grua, 2010.

; BONALUME NETO, Ricardo. Brazilian Expeditionary Force in World War II. Oxford, UK: Osprey, 2011.

_; OLIVEIRA, Dennison de. Raça e Forças Armadas: o caso da Campanha da Itália (1944-45). Estudos de História. Franca, vol.8, n.1, 2001.

McCANN, Frank D. A Nação Armada. Recife: Guararapes, $1982 .{ }^{1}$

Press, 1973. . The Brazilian-American Alliance, 1937-1945. Princeton: Princeton University ; FERRAZ, Francisco C. A. Brazilian-American Joint Operations in World War II, In: MUNHOZ, Sidnei; SILVA, Francisco Carlos Teixeira da (eds.). Brazil-U.S. Relations in the 20th and 21st Centuries. Maringá: EDUEM, 2013.

MELLO, José Luiz Ribeiro (org.) A legislação do ex-combatente. Rio de Janeiro: Ed. Expedicionário, 1978.

METTLER, Suzanne. Bringing the State back in to civic engagement: policy feedback effects of the G. I. Bill for World War veterans. American Political Science Review. Vol. 96, n. 2, june 2002.

METTLER, Suzanne. The G. I. Bill and the making of the Greatest Generation. New York: Oxford University Press, 2005. 
OLSON, Keith W. The G.I. bill, the veterans, and the colleges. Lexington: University Press of Kentucky, 1974.

ONKST, David H. "First a Negro...Incidentally a Veteran": Black World War Two Veterans and the G. I. Bill of Rights in the Deep South, 1944-1948. Journal of Social History. Vol. 31, Nº3, Spring, 1998.

PAIVA GONÇALVES, Carlos. Seleção Médica do Pessoal da F.E.B. Histórico, funcionamento e dados estatísticos. Rio de Janeiro, 1951.

PIEHLER, G. Kurt. Remembering War the American Way. Washington: Smithsonian Books, 1995.

PRATT, George K.; STEVENSON, George S. Soldier to Civilian: Problems of Readjustment. New York: McGraw-Hill, 1944.

ROSE, Kenneth. Myth and the Greatest Generation: a social history of Americans in World War II. New York: Routledge, 2008.

ROSENHECK, Uri. Olive Drab in Black and White: the Brazilian Expeditionary Force, the U.S. Army and Racial National Identity. XXIX International Congress of the Latin American Studies Association (2010, October 6-9).

ROSS, Davis R. B. Preparing for Ulysses: politics and veterans during World War II. New York: Columbia Unievrsity Press, 1969.

SAXE, Robert Francis. World War II Veteran's Challenge to the Post-War Consensus. New York: Palmgrave Macmillan, 2007.

SCHULZ, John. O Exército na política. Origens da intervenção militar. São Paulo: EDUSP, 1994.

SEVERO, Richard \& MILFORD, Lewis. The wages of war: when America's soldiers came home. From Valley Forge to Vietnam. New York: Touchstone, 1990.

SILVEIRA, Joaquim Xavier da. A FEB por um soldado. Rio de Janeiro: Nova Fronteira, 1989.

SKOCPOL, Theda. Protecting Soldiers and Mothers. The Political Origins of Social Policy in the United States. Cambridge, Mass./London: The Belknap Press of Harvard University Press, 1992.

SOARES, Leonércio. Verdades e vergonhas da Força Expedicionária Brasileira. Curitiba: Ed. do autor, 1985. 
SODRÉ, Nelson Werneck. História militar do Brasil. Rio de Janeiro: Civilização Brasileira, 1978.

SPARROW, John. History of Personnel Demobilization in the United States Army. Washington D.C.: Center of Military History/United States Army, 1952.

SPINDLER, G. D. The Doolittle Board and Cooptation in the Army. Social Forces, vol. 29, n. 3, March 1951, 305-310.

STOUFFER, Samuel, et al. The American Soldier. Volume 1: Adjustment during Army life. Princeton: Princeton University Press, 1949.

TERKEL, Studs. "The Good War": an oral history of World War II. New York: The New Press, 1984.

The Health Scandal. The Nation. July 22, 1944.

VAN ELLS, Marc D. To Hear Only Thunder Again. America's World War Veterans Come Home. Lanham, MD: Lexington Books, 2001.

WALLER, Willard. The Veteran Comes Back. New York, Dryden Press, 1944.

WECTER, Dixon. When Johnny Comes to Marching Home. Cambridge: Houghton, 1944.

WYNN, Neil A. The "Good War": The Second World War and Postwar American Society. In: Journal of Contemporary History. SAGE Publications, 1996.

Texto recebido em 15 novembro de 2013 e aprovado em 22 abril de 2014 